SCJR 11, no. 1 (2016): 1-3

\title{
Matthew A. Tapie \\ Aquinas on Israel and the Church: The Question of Supersessionism in the Theology of Thomas Aquinas
}

(Eugene, OR: Pickwick, 2014), xv + 198 pp.

\author{
HOLLY TAYLOR COOLMAN \\ htc@providence.edu \\ Providence College, Providence, RI 02918
}

In Aquinas on Israel and the Church, Matthew Tapie has taken on a set of questions that sits at the very heart of Jewish-Christian engagement. He has done so, furthermore, by exploring texts of unusual importance. Although there have been a number of attempts to construct a fully post-supersessionist Christian theology, too often these proposals have neglected premodern Christian thinkers. Tapie follows in the footsteps of those who have begun to look to a source once considered unlikely to provide assistance: Thomas Aquinas. In this detailed consideration of Aquinas' thought on the matter, therefore, Tapie points his readers to a source whose influence is difficult to overestimate, and also further unfolds ways in which Aquinas' thought is valuable for post-Vatican II theology. Aquinas on Israel and the Church will assist Christian theologians in meeting-as Pim Valkenberg rightly says in the foreword- "the challenges of the document Nostra Aetate that we have barely begun to realize" (p. xii).

Within the field of Aquinas studies, furthermore, Tapie's work elaborates our understanding of the Common Doctor's thought. It is especially crucial that Tapie has considered the treatment Aquinas gives these matters not only in his magnum opus, his Summa Theologiae, but also in his biblical commentaries. In the commentaries, and especially the commentary on Romans, a more positive account of Judaism and of the Law emerges. By considering these sources Tapie reveals greater complexity in Aquinas' thought and signals the way in which he might assist Christians who are concerned about improving Jewish-Christian relations.

In this relatively brief volume, Tapie has taken on an ambitious project, with several components. He begins by surveying recent scholarship on the category of supersessionism in general, as well as scholarship considering whether and how Aquinas' thought exhibits supersessionism. Tapie draws from Kendall Soulen's discussion of the different forms of supersessionism. "Punitive" supersessionism, the harsher form, involves straightforward rejection by God of the Jewish people. "Economic" supersessionism, more immediately relevant in Tapie's consideration 
of Aquinas, is the claim that "Christ's fulfillment of Jewish ceremonial law renders its continued observance obsolete and indeed damnable" (p. 20). Tapie then considers analyses of Aquinas from Michael Wyschogrod, Matthew Levering, Bruce Marshall, and Steven Boguslawski, with Soulen's second definition especially in mind. Tapie thus helpfully isolates a very specific question for consideration: 'the question of supersessionism in Aquinas' theology turns on whether Jewish observance of the Law can have a positive theological significance, or whether it is always 'dead and deadly"' (p. 42, quoting Wyschogrod). He goes on to look closely at Aquinas' account of the matter in the most relevant New Testament commentaries: Hebrews, Romans, Galatians, and Ephesians.

This specific focus is highly salutary and sets the stage for future constructive work. Previous Christian scholarship which spoke, for example, only of "continuity" or "discontinuity" in the move from Old Covenant to New is simply not subtle enough to allow the kind of scholarship that is needed. Investigation into Aquinas' commentaries, furthermore, is much needed. (Indeed, many areas of research into Aquinas' thought are waiting to be expanded and enriched by study that goes beyond the Summa Theologiae.) And the project yields important fruit. Going forward on the basis of these two decisions, Tapie come to a crucial, central conclusion: Aquinas anticipates and agrees with the Second Vatican Council's affirmation, in Nostra Aetate, that God does not abrogate the election of the Jews. Taking his inspiration from an in-person conversation with Wyschogrod, Tapie translates a claim Aquinas makes in his Romans commentary (Ad. Rom. 3.1.253) thus: "For if the Jews' prerogative were abrogated on the account of the unbelief of some, it would follow that man's unbelief would nullify God's faithfulness - which is an unacceptable conclusion" (p. 99).

At the same time, this book does have some weaknesses. Tapie's treatment of the secondary sources is lacking at certain points. He does not, for example, capture the full nuance of Levering's work, even if it may be the case that Tapie would want to disagree with Levering's position in the end. Levering says that Aquinas does not think that Jewish Christians are obligated to keep the ceremonial law as individuals, but he nevertheless certainly does not simply claim that the Law is obsolete. Rather, Aquinas thinks that Jews who come to Christ fulfill the ceremonial law in Christ, as they participate in his (not simply spiritual, but bodily) Torah-observance.

More importantly, questions arise regarding Tapie's reading of the Romans commentary. In particular, he focuses on the way in which Aquinas speaks in the Romans commentary of the "present spiritual benefits" of special Jewish prerogatives mentioned by Paul-including the prerogative of "the Law" (p. 105). This discussion of present - and not merely former-prerogatives means, Tapie argues, that Aquinas here counts the ceremonial law as "upheld" (p. 108). It is not clear, though, that a "present spiritual benefit" of the Law is the equivalent of the ceremonial law, and that the obligation of Jews to observe the ceremonial law continues to function just as it did prior to Christ's life, death, and resurrection. Indeed, as Tapie notes, when describing the ceremonial law directly, Aquinas uses the term "upheld" (statuuntur) specifically and personally in relation to Christ: 
"being figures, they were upheld and fulfilled by the fact that the truth signified by them is shown forth in the faith of Christ." (p. vi, citing Ad. Rom. 3.4.321). This, though, would seem to lead more easily to a profoundly Christocentric account of the ongoing enactment of the ceremonial law, more like the claim of Levering as described above. Such a view could be more easily reconciled with Aquinas' claims in other texts, but it would also constitute an instance of "economic supersessionism," at least as that term is defined by Tapie, following Soulen, above. These are complex questions, but further discussion and clarification is required.

None of this, though, undermines the central importance of Tapie's work. If anything, the questions raised call for constructive work that takes into account the subtle distinctions that Aquinas draws. Even when we find that certain of Aquinas' conclusions are to be left behind, we well may find that he provides the structures of thought that allow us to work out the wisdom of Nostra Aetate in full. 